\title{
Third culture children in the Czech Republic: the influence of parents' cultures on preparing for school
}

Streszczenie: Dzieci trzeciej kultury są stosunkowo nowym podmiotem badań w Republice Czeskiej. Niniejsze badania jakościowe obejmują dzieci, których językami ojczystymi są czeski i angielski, a każdy z rodziców ma inne zaplecze kulturowe. Ich dzieci uczęszczające do szkół podstawowych w Republice Czeskiej muszą często pokonać innego rodzaju problemy dotyczące przygotowania się do nauki szkolnej niż ich jednokulturowi rówieśnicy. W części metodologicznej staram się zidentyfikować te problemy oraz powody zamieszkania tego typu rodzin mieszanych w Republice Czeskiej, mimo że nie zawsze jest to dla ich dzieci łatwe.

Słowa kluczowe: dzieci, język angielski, partnerstwo międzykulturowe, przygotowanie do nauki szkolnej, Republika Czeska, trzecia kultura, analiza sytuacyjna

\section{Introduction}

The fact that people migrate and settle in other countries does not mean that they are able to establish seamless relationships with other cultures (Breger and Hill, 1998, p. 85). Roer-Strier and Ben Ezra (2006, p. 44) give a description of the various factors influencing the occurrence of intercultural relationships in individual societies. The primary factor is migration, which increases the likelihood of contact between individuals from different cultural environments. Then there is the cultural factor, which includes cultural and social distance between individual societies. The more foreign languages an individual speaks and the longer he/she stays in the host country, the more likely he/she is to establish an intercultural partner relationship, especially if the individual is young, educated, has no religious beliefs, and has a good knowledge of the foreign language. As stated by Romano (2008, p. 4), these individuals do not have a firm connection with their own culture. Roca and Urmenet (2013, p. 571) found a positive relationship between the frequency with which intercultural relations and cultural proximity occur, which of 
course does not mean that they view their similarity in the same way (Evanoff, 2006, p. 427). These individuals logically bring their different cultural perspectives and a different level of understanding with regard to running a household into the common background (Kalmijn, 1998, p. 399). In addition to the need to deal with prejudices in their relationship, intercultural couples may also face discrimination from their surroundings, which may affect the way they experience their relationship (O’Neal et al., 1997). Apart from the mentioned language and communication, specific factors that may cause potential difficulties due to the different cultural environments include the adaptation of the partner coming from another country to life in a foreign country, friends, raising children, gender roles, and traditions. Frame (2004, p. 230) came to similar conclusions on language, raising children, and gender roles. Rodríguez-García (2006, p. 22) suggests that raising children in intercultural partnerships can be more difficult than raising children in an intracultural partnerships. This is based on the concept of intracultural and intercultural partner relationships as they are conceptualized by Piller (2007).

In the Czech Republic, as a country with a relatively small ethnic diversity, the relationships are mainly between native Czechs and foreigners. According to the Czech Statistical Office (CZU, 2016), there were 480,294 foreigners in the Czech Republic with a stay of more than 12 months in 2016. This study also deals with this partnership, so we define intercultural partnerships as a partnership in which each partner has a different mother tongue.

From the family perspective, the culture environment of a family, whether it be an intercultural or an intracultural family, should be a place where all members feel safe and content, as the family culture should stem primarily from unity, reciprocity, and the common orientation of the whole family (Verešová, 2009). Barnes and Rowe (2008) conceptualize the family as the building material of society, which must of course face many dangerous situations. The risks that families today have to prevent are related mainly to the overall transformation of family life that has taken place over the course of the last decades.

\section{Parental support in home preparation for school education}

Home preparation is a well-established tradition in the Czech Republic. It is an extracurricular activity that is closely linked to school education. It is a continuation of school work at home (Bělohradská et al. 2001, p. 264). At 
present, home preparation, or homework, is a highly discussed topic (Cooper, et al., 2006, Kralovec and Buell, 2000, Bennett and Kalish, 2006, Kohn, 2006). It takes a lot of time away from children and may become a source of conflict (Kohn, 2006). It can create conflict not only in the family, but can also interfere with the otherwise smooth communication between the parents and the school. Researchers do not currently agree on whether homework brings more positive or negative effects, but given that children live in the present and are preocuppied with what is happening right now, it can not be expected that they will do their homework with enthusiasm. It is necessary to take into account the actual possibilities and the personal limits of the child and his/her resistance to stress (Beníšková, 2007, p. 48). In the event of setbacks and various school failures, the child may feel disappointment, have an aversion to further home preparation, and may even start to doubt his/her self-sufficiency or learning abilities. Useem and Cottrell (1996) state that although children from intercultural families have to cope with more demanding conditions when preparing for education, a large percentage of these children will achieve higher education at a master's or postgraduate level. In fact, as little as $2 \%$ of these children end up with only a high school education in the United States (Useem and Cottrell, 1996).

\section{Methodology 4}

The aim of our research is to find out what difficulties are met by children in home preparation from families where the partners come from different cultures and at the same time have different mother tongues. Although the children are exposed to the Czech language since birth, their main mother tongue is English. The criteria for the research were as follows (see Table 1):

Table 1. Criterion for Research

\begin{tabular}{|l|l|l|}
\hline \multicolumn{1}{|c|}{ 1. criterion } & \multicolumn{1}{|c|}{ 2.criterion } & \multicolumn{1}{c|}{ 3.criterion } \\
\hline $\begin{array}{l}\text { Children must live in families } \\
\text { where each partner has a different } \\
\text { mother tongue and one of these } \\
\text { languages is English. }\end{array}$ & $\begin{array}{l}\text { The second criterion: families } \\
\text { with children (child) in elemen- } \\
\text { tary school in the Czech Republic } \\
\text { (ISCED 1,2). }\end{array}$ & $\begin{array}{l}\text { Primary schools attended by these } \\
\text { language, according to the Czech } \\
\text { educational curriculum and be en- } \\
\text { rolled in the Register of the Minis- } \\
\text { try of Education, Youth and Sports. }\end{array}$ \\
\hline
\end{tabular}

For the purpose of meeting the research goal, a qualitative research strategy involving semi-structured interviews was chosen. The interview was 
conducted with six participants - parents who meet the above-mentioned criteria. In the data interpretation, the authentic statements of the respondent are written in cursive and are entered in parentheses on behalf of the participant (see Table 2).

Table 2. Participants chosen for the research

\begin{tabular}{|l|l|l|}
\hline FAMILY & CHILDREN & $\begin{array}{l}\text { LANGUAGE OF THE COMMUNICATION } \\
\text { IN THE HOME ENVIRONMENT }\end{array}$ \\
\hline A & Name* and Age & \\
\hline B & $\begin{array}{l}\text { Jane, 13 } \\
\text { Vivian, 10 }\end{array}$ & English, exceptionally Czech \\
\hline C & $\begin{array}{l}\text { Karen, 8 } 11 \\
\text { Lucas, 13 }\end{array}$ & English, exceptionally Czech \\
\hline
\end{tabular}

\begin{tabular}{|l|l|l|l|l|l|l|}
\hline FAMILY & \multicolumn{3}{|c|}{ MOTHER } & \multicolumn{3}{c|}{ FATHER } \\
\hline & Name* & Nationality & Mother Tongue & Name* & Nationality & Mother Tongue \\
\hline A & Ludmila & CZ & Czech & Josh & SA & English \\
\hline B & Petra & CZ & Czech & Jamie & SA & English \\
\hline C & Wendy & SA & English & Carl & SA & Afrikaans \\
\hline
\end{tabular}

"Acccording to the anonymization, the real names of the participants were changed

\section{Data analysis}

The obtained research material was analysed using situational analysis procedures. In the context of the study, we focused on the environment in homes, the impact the cultures of the individual participants have on this environment, and the difficulty of home preparation for school education. The analysis of the data obtained was carried out in the following steps:

1. All the interviews were transcribed and subjected to open coding completed with notes.

2. A messy map was subsequently created based on the identified elements (see Figure 2).

3 . In the next step, all the codes were cagorized.

4. The further analytical work consisted of a relational analysis focusing on the elements that determine home preparation in the case of pupils from intercultural partnerships (see Fig. 3). 
Figure 2. Basic Map - Messy Map (own research, 2017)

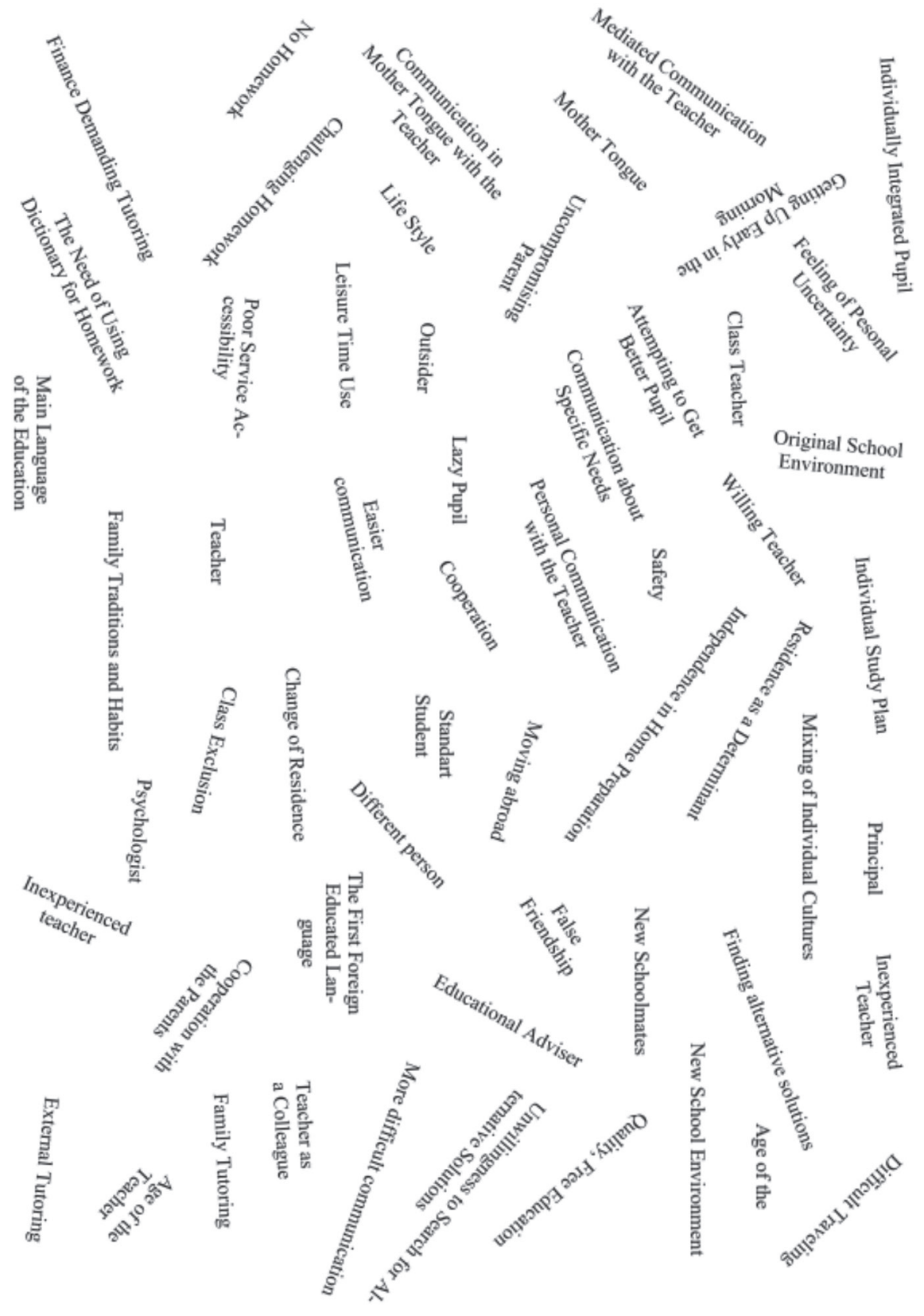


Figure 3. Relative analysis focusing on the home environment and cultural determinants (own research, 2017)

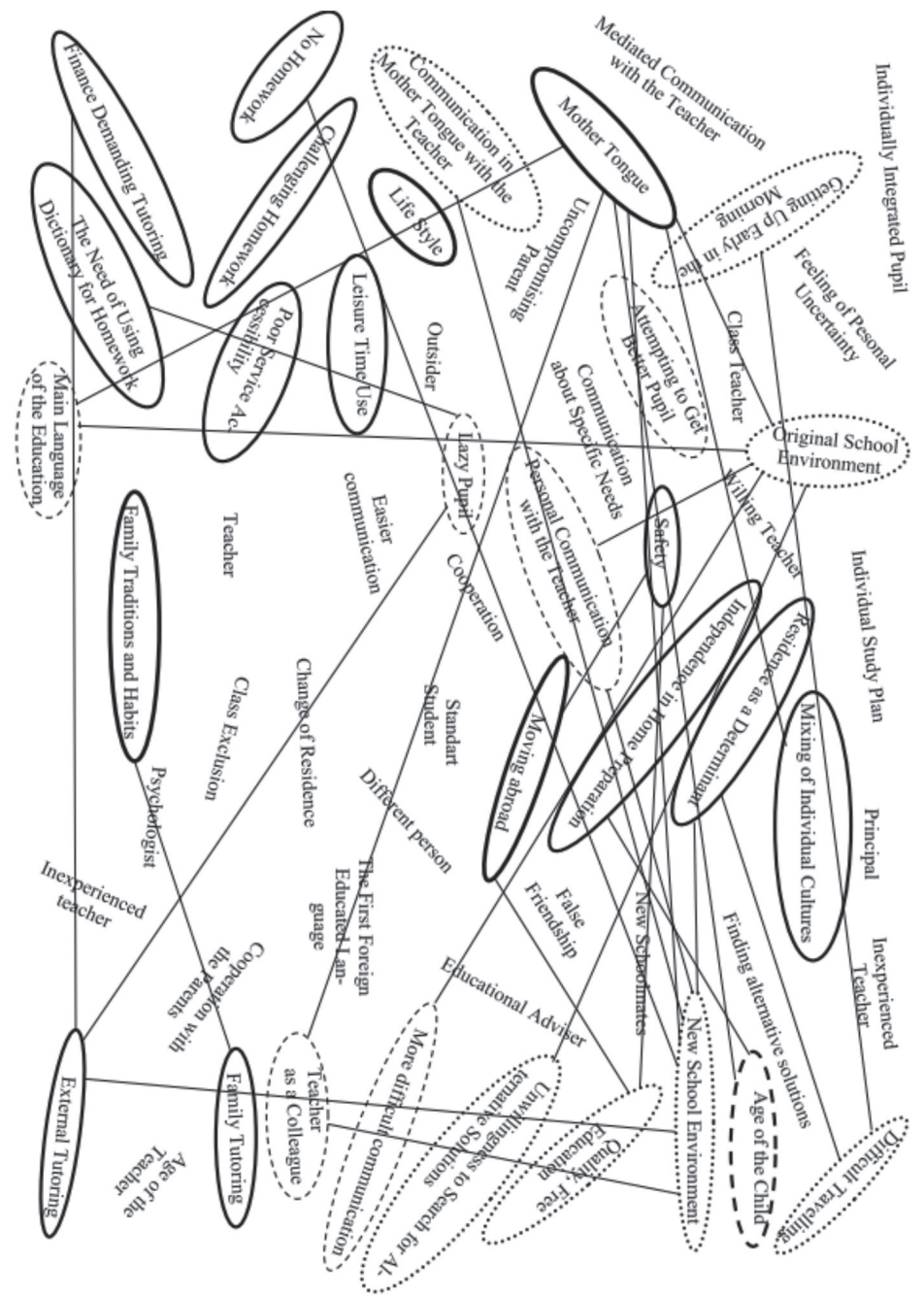

Labeling of individual elements / folders based on their belonging to the key category:

$\bigcirc$ - Home Environment, Cultural Determinant

- Collective Actors, Discursive Construction of Individuals in the Collective, Communication

- School Environment, Teacher's efforts, Position of the Child in School

ミン - Time Based Codes 


\section{Results}

The individual participants were given the choice of which language they would prefer to communicate it. Participants that are originally from South Africa chose English, even an individual who has a B2 level of proficiency in the Czech language according to the Common European Framework of Reference for Languages: Learning, Teaching, Assessment (CEFRL). Participants who are originally from the Czech Republic communicated with the researcher in Czech. Evidently, the duration of the stay in a foreign country or the influence of the environment does thus not matter, and the native language remains the preferred language in situations where the person has the choice. Interestingly, participants communicate with each other only in English when they are in a family environment. They have stated that this language is easier for them.

In the data interpretation, the authentic statements of the participants are written in cursive and are added in parentheses on behalf of the individual participant. For greater clarity, the transcripts were translated into English by a researcher. The researcher's knowledge of this language is at level C1.

The data analysis shows that the approaches of families to school preparation are varied.

My daughter has Skype tutoring, the travelling was to difficult for us. (Josh) I had an tutor, but it didn't work out. D. did not behave well, she was constantly angry. Than the lady said we shouldn't come anymore. Recently children attend a different school, where they have tutoring immediately after lessons in the school building. [...] (Wendy)

In particular, it can be observed that all children need to pay increased attention during home preparation, and individual families deal with this problem in a different way. The location of the family's residence has a strong influence on the decision of how to help the child.

It was a big problem for us, regularly travelling there and back. One Czech lesson took me three hours of my time. Picking up the children from school, bring them to (town name - due to anonymization, the town name was deleted), wait and back home. When I wasn't working, I was driving. This changed at the moment, when my children changed their school. Now they have tutoring in the school building. [...] (Wendy) 
Home preparation for school is influenced not only by the school itself, how busy the parents are, and the other factors mentioned above, but to a great extent also by the different customs and traditions in the family, namely the way in which roles are divided in the household and what the family prioritizes from a cultural point of view.

In the evening we all meet together at the table and eat dinner, so I have to cook every day. That takes me a lot of time too. [...] My husband is often still at work and I don't have time to do homework with the children. (Wendy) [...] At home we try to speak English as much as we can, we almost don't use Czech. Not even me, although it's my native language.

The individual parents come from very different cultures. The question has thus emerged of why they live in the Czech Republic despite the fact that it is often very difficult for their children. All families agreed on three codes: security, moving to a foreign country, and high-quality, free education.

Security:

[...] I don't want to worry about my children when they go out. [...] (Josh)

[...] We don't live behind the walls. South Africa is a beautiful country, but being white means, that you are constantly afraid about your safety. You must protect yourself with various alarms, security, high fence, e.g. It's a nightmare. [...] (Carl)

Moving abroad:

We'd lived in South Africa before and we'd like to come back. But after the kids finish their education. Certainly, at latest for our retirement age. (Jamie) [...] We are thinking about it, but only theoretically. We like the Czech Republic, it's safe here, piece, but the language is terribly difficuilt. But we would like to stay in Europe. Perhaps, in Austria or Belgium. [...] (Wendy)

High-quality, free education. This was a very interesting code for the researcher. All the families praised the education system in the Czech Republic, despite the fact that it is often very difficult for them.

[...] In South Africa, if we want to give our child a high-quality education, it'd cost us most of the money we'd earn. And we would't have any money left for school supplies, travelling, living, security and everything else. Although public schools are over there, but in that case, Karen'd be the only white child, and she would't learn much. And we didn't want that. (Petra) Education in South Africa is very expensive. Although I went to school over there, but it was back then during Apartheid when everything was different than today. (Josh) 


\section{Position map}

One of the characteristics of the classic grounded theory that is often criticized is the over-simplification of meanings, whereby deviations in the statements of research participants from the central categories of meaning are not reflected or are viewed as deviations from the norm (Clarke, 2003, 2005, Thomas and James, 2006).

In the position map (see Figure 3), positions are then taken based on excerpts from the anecdotes of the respondents with regard to these two meaning axes - the influence of cultural determinants on the child's home preparation for school education and the intensity of home preparation for school education.

Figure 3. Position map concentrating on the influence of cultural determinants on child's home preparation for school education and the intensity of home preparation for school education (own research, 2017)

A - Ludmila and Josh, two children, 11 and 13 years old.

B - Petra and Jamie, one child 8 years old.

C - Wendy and Carl, 2 children 11 and 13 years old.

(more detailed description of the families is in Table 1)

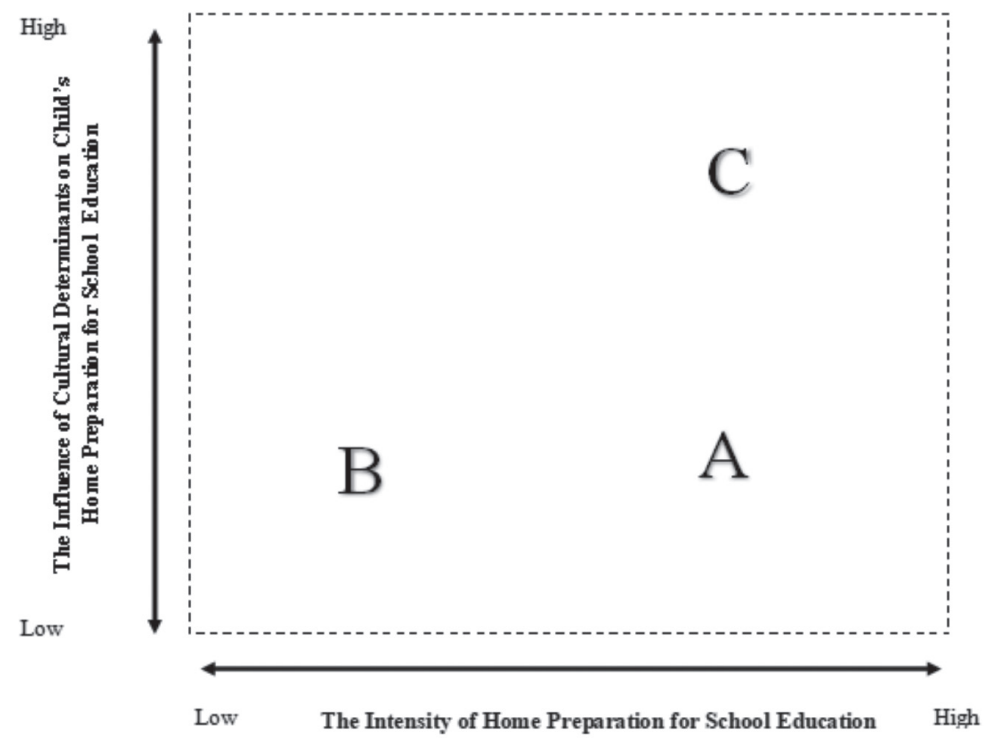


It is clear from the position map that the preparation for school education is the most difficult for family $\mathrm{C}$. It follows from the interview that cultural influences that do not originate in the Czech Republic have the greatest affect on their family environment. In the evenings we all meet together at the table and eat dinner, so I have to cook every day. That takes me a lot of time too.[...] (Wendy) [...] my husband can't speak Czech at all. (Petra) [...] but the language is terribly difficuilt.[...] (Wendy)

Due to the difficulty of home preparation, which was not directly proportional to the school results of children and the demanding communication with the first primary school, parents decided to switch over to a different primary school. [...] This didn't exist in the previous school. There was no one willing to talk to us and when they could, they just criticized and only in Czech. Nor my husband or me were able to understand. (Wendy)

A considerable proportion of the young adult from third culture change colleges and/or majors two or three times (Useem, Cottrell, 1996).

Although the cultural determinants also influence family A, this family has adopted the Czech culture to a greater extent and the influence of foreign culture is not as apparent. I'm almost Czech, just not with Czech passport. I was born in South Africa to South African parents, but I spent more than half of my life here. (Josh) However, even they were forced to deal with problems that their daughter had at school in the past, but the communication with the school was very good. There were problems with bullying, and somebody kept stealing her things at school. Their daughter's classmate did not like that she speaks English well (among other things). There were more such problems in the classroom. Finally, we had her moved to another class. (Ludmila) The family which is the least affected by cultural determinants and thus has easier preparation for school education is family $\mathrm{B}$, despite the fact that this family lived abroad in the past. As parents, they admit that it is partly because their daughter is still only in the first grade. Karen gets homework but she's in the first class, so she's still very careful. I always sit with her and, when she needs it, I help her. (Petra)

\section{Conclusion}

This qualitative study focuses on the influence of parents' cultures on the home preparation of a child for school education in families in which the parents have different mother tongues in addition to their different cultures. This has a considerable influence not only on the preparation for school. It 
also creates obstacles with regard to school attendance, namely in communicating with the teacher or understanding the explanation of the curriculum. This situation emerges despite the fact all the children from the studied families were born in the Czech Republic and had been in contact with the Czech language since their early childhood. The data obtained show that the influence of both the language and cultural situation of the family is transferred to their children from the home environment to the school environment. Families try to integrate their children into the Czech education system by providing them with from a certain age. Although it is time-consuming for them, parents are willing to support them, because they know that the afterschool tutoring is often too much to handle for them. However, this afterschool tutoring must not affect the original customs and traditions which they have brought with them from their native country. This is confirmed by family C (Carl and Wendy), for whom the evening ritual of preparing food and having a warm dinner together is very important. This ritual must not be affected by the after-school tutoring, not even if the children have not yet finished their homework or preparation for school by that time.

In exceptional cases, families are willing to move their children to a different primary school, which is not unusual for these children, as is described in the study of Useem and Cottrell (1996). They do so at the moment when they feel that the communication with the teacher is very difficult for them. Poor relationships are reflected in the school results of the child (Rabušicová, in Rabušicová et al., 2004, p. 12). Quality interaction is thus of great importance (Šed’ová, in Rabušicová et al., 2004, p. 75). The new school does not burden these children with an unnecessarily large amount of homework. On the contrary, they try to follow a schedule where most of the homework tasks are completed during school hours before they leave school. It is evident that home preparation concerns not only the pupils themselves, but also teachers and parents.

From the data obtained, it is also evident that families have created their own platform at home which is different from the typical monocultural families in the Czech Republic. This platform affects their children to a certain extent and, subsequently, their preparation for school. There is a mix of two very different cultures in the family. We can, therefore, confirm that the diffusion of cultures can not really be simply defined as $A+B=C$, but should be defined as $A+B \neq C$ (Adair et al., 2006, p.209). Compulsory school attendance enters the mix from the third side, and different families each try to cope with it in their own individual way that suits them best. At the same 
time, they try to overcome all the obstacles that stand in the way of their efforts to adapt to life in the Czech Republic while preserving part of their "original self".

A look at how children are influenced by the different culture of their family and how difficult school preparation is for them with regard to the child's leisure time would surely be interesting as well.

\section{Bibliography}

Adair, W.L., Tinsley, C.H. and Taylor, M.S. 2006. Managing the intercultural interface: Third cultures, antecedents, and consequences. Research on Managing Groups and Teams. 7, pp. 205-232

Barnes ,M. and Rowe, J. eds. 2008. Child, youth and family health: strengthening communities. Chatswood, N.S.W: Elsevier Australia.

Bělohradská, J., Solfronk, J. and Urbánek, P. 2001. Problematika zatíženosti žáků základní školy domácí přípravou. Nové možnosti vzdělávání a pedagogický výzkum. Sborník z IX. celostátní konference ČAPV s mezinárodní účastí. Ostrava: Pedagogická fakulta OU, ss. 264-268.

Beníšková, T. 2007. První tř́dou bez pláče: výběr školy, první školní den, učitelé a spolužáci, domácí príprava, mimoškolní činnost, když nastanou problémy. Praha: Grada.

Bennett, S. and Kalish, N. 2006. The case against homework: How homework is hurting our children and what we can do about it. New York: Crown.

Breger, R. and Hill, R. 1998. Cross-cultural marriage: Identity and choice. New York: Bergamon.

Clarke, A.E. 2005. Situational analysis. Grounded theory after the postmodern turn. Thousand Oaks: Sage.

Cooper, H., Robinson, J.C., and Patall, E.A. 2006. Does homework improve academic achievement? A synthesis of research, 1987-2003. Review of Educational Research. 76 (1), pp. 1-62.

Frame, M.W. 2004. The Challenges of Intercultural Marriage: Strategies for Pastoral Care. Pastoral Psychology. 52 (3), pp. 219-232.

Kalmijn, M. 1998. Intermarriage and Homogamy: Causes, Patterns, Trends. Annual Review of Sociology. 24 (1), pp. 395-421. http://www.annualreviews.org/doi/10.1146/annurev.soc.24.1.395 (3.03.2018).

Kralovec, E. and Buell, J. 2000. The end of homework: How homework disrupts families, overburdens children, and limits learning. Boston: Beacon. 
Kohn, A. 2006. The homework myth: Why our kids get too much of a bad thing. Cambridge, MA: Da Capo Press.

O'Neal, V.P., Brown, P.M., and Abadie, T. 1997. Treatment implications for interracial couples. Cross-cultural practice with couples and families. New York: The Haworth Press, Inc.

Piller, I. 2007. Cross-cultural communication in intimate relationships. Handbook of Intercultural Communication. Berlin and New York: Mouton de Gruyter.

Průcha, J., Walterová E. and Mareš. 2103. J. Pedagogický slovník. Praha: Portál.

Rabušicová, M., Šed’ová, K., Trnková, K. and Čiháček, V. 2004. Škola a (versus) rodina. Brno: Masarykova univerzita.

Roca, J., and Urmeneta, A. 2013. Bi-national Weddings in Spain: A Recent and Increasingly Frequent Phenomenon in the Context of the Globalization of the Marriage Market. Procedia - Social and Behavioral Sciences. 82, pp. 567-573. http://linkinghub.elsevier.com/retrieve/pii/ S1877042813013785 (3.4.2018)

Rodríguez-García, D. 2006. Mixed Marriages and Transnational Families in the Intercultural Context: A Case Study of African-Spanish Couples in Catalonia, Spain. Journal of Ethnic and Migration Studies. 32 (3), pp. 403-433. https://ddd.uab.cat/pub/artpub/2006/67766/PREI2008_jouethmigstu.pdf (3.4.3018)

Roer-Strier, D. and Ben Ezra, D. 2006. Intermarriages between Western women and Palestinian men: Multidirectional adaptation processes. Journal of Marriage and Family. 68 (1), pp. 41-55

Romano, D. 2008. Intercultural marriage: promises and pitfalls. Boston, MA: Intercultural Press.

Schwartz, S.H. 1992. Universals in the content and structure of values: Theory and empirical tests in 20 countries. Advances in Experimental Social Psychology. 25, pp. 1-65

Schwartz, S.H. 1994. Are there universal aspects in the content and structure of values? Journal of Social Issues. 50 (4), pp. 19-45.

Thomas, G. and James, D. 2006. Reinventing grounded theory: Some questions about theory, ground and discovery. British Educational Research Journal. 32 (6), pp. 767-795.

Useem, R.H. and Cottrell, A.B. 1996. Adult Third Culture Kid. Strangers at Home: Essays on the Effects of Living Overseas and Coming "home" to a Strange Land. Aletheia Publication, pp. 22-35. 


\title{
Third culture children in the Czech Republic: the influence of parents' cultures on preparing for school
}

\begin{abstract}
Third culture children are relatively a new research topic in the Czech Republic. This qualitative study pursues children, whose native languages are Czech and English, and each of their parent is from different cultural backround. Their children attend primary schools in the Czech Republic, often encounter different problems in preparing for school education than their monocultural peers. In the methodological part, attermpts are made to identify these problems, together with the reasons why these families live in the Czech Republic, although it is not always easy for their children.
\end{abstract}

Keywords: children, English language, intercultural partnership, school preparation, Czech Republic, third culture, situational analysis

Translated by Lenka Venterová 